させて $5 \mathrm{~mm}, 10 \mathrm{~mm}$ の間隔で分割照射した，使用電離

槽: Victoreen r-meter $25 \mathrm{mR}$ 用, $250 \mathrm{mR}$ 用。

線源: $\mathrm{Ra}^{226}$, 透視 (山城 $\mathrm{C}$ 型 $50 \mathrm{kVp} 2 \mathrm{~mA}$ )

結果 : $25 \mathrm{mR}$ 用電離槽を用い, Fig. (II)の方法で求め た曲線で囲まれた面積は

$10 \mathrm{~mm}$ の時 $89 \% 5 \mathrm{~mm}$ の時 $86.5 \%$

$250 \mathrm{mR}$ 用電離槽を用い，Fig. (II) の方法で求めた曲 線で井まれた面積は

$10 \mathrm{~mm}$ の時90\% $5 \mathrm{~mm}$ の時 $87 \%$

Fig. ( I )の方法で照射を行ない，曲線で囲まれた面積 を求めた。

$25 \mathrm{mR}$ 用電離槽 : $10 \mathrm{~mm} \phi 78 \%$

$250 \mathrm{mR}$ 用電離槽 $\left\{\begin{array}{c}5 \mathrm{~mm} \phi 51 \% \\ 10 \mathrm{~mm} \phi 72 \%\end{array}\right.$

$250 \mathrm{mR}$ 用電離槽を用い Fig. I の方法で照射した時の グラフが左右非対称でああるのは，中心電極の彎曲のた めと考えられる。

結論 : 以上の結果から考え電極間電圧の不均等性が認 められ，指示值も低い值を示す可能性があり，電離構の 方问依特性も考えられる。

\section{9. $\mathrm{Co}^{60}$ 運動照射法の線巣写真表示法（第 4 報）}

岩手医科大学中央レントゲン部 樋口喜代治・佐々木功

\section{〔緒官】}

$\mathrm{Co}^{60}$ r線運動照射におけるパラフィンファントーム 内での線量分布を写真法で撮影，プリントするととによ り線巣形を簡易に知る方法について既に報告した通りで あるが今回は肺野の照射について検討した。

[方法]

健康成人男子の上半身パラフィン像を作り右肺門部， 左中肺野中心部，を仰卧位で深部 $10 \mathrm{~cm}$ のとろを照射 目標とした。

照射中心部を縦横に鋸で紐隙を作る．その細隙にソフ テックス FGフィルムを挿入一間照射，振子照射 $\left(80^{\circ}\right.$ $120^{\circ}$ ) の場合をそれぞれ撮影（空中線量約 $20 \mathrm{R}$ ) コピー して 40\%，60\%，80\%，100\%の線巣形についてその信 頼性について検討した。

[結論]

線巣形を確認する方法しして郜床上簡易に使用できる.

\section{0. 人体横断面計測器について}

立川共済病院放科

猪狩 定典・中田 好抒

$$
\text { ポニー原子工業 } \mathrm{KK}
$$

南勲

放射線治療計画の一環として，まず線量分布図を作成 せねばならないが，それには照射部位の横断面図が必要 である。従作は鉛線またはそれに代る計測法にて横断面 図を測定して来たが，乙れらの方法はいずれる難点が多 く正確さを欠くことなどから新らしく人体横断面計測器 を考案し，その機構および使用方法等について検討した ので報告する。

本体は逆U字型をなし，半円の部分 (半径 $25 \mathrm{~cm}$ ) は10 度間隔に目盛を，雨端の足の部分 (長さ $13 \mathrm{~cm}$ )では $1 \mathrm{~cm}$ 間隔に目盛をきざみ，測定ピンが固定するようマグネッ 卜を使用する。プロット板は本体と同一関係の目盛を有 し，測定ピンは 0〜 $25 \mathrm{~cm}$ までのスケールを有する．特 長を2，3あげると，あらかじめ透視あるいは位置決め装 置において病栄部を確認し皮膚面にマークした個所にお いて,

（1）計測中心あるいはその垂線に対しての皮膚面まで 距離を数值的に計測できる。

（2）プロット板を用いて上記の計測值をプロットし， 作図するととができる。

（3）計測時点において体の厚さ，幅および病果までの 深さ（前後左右方向）を知ることができる.

(4)（3)において得られた病巣位置と丸型方眼紙の中心 とを合わせて作図すれば各角度における病巣皮䖉間距離 を知ることができる。

以上の点から運動照射とくに Tangential Rotation に おいて要望される正確な横断面図を得るととが可能であ るほか，近年治療装置の進歩と己もに開発された位置決 め装置によるX線写真より病巣の位置，そのひろがりを 明確に作図できることなどから，本横断面計測器は放射 線治療計画に立分役立て得ると思われる。

101. 東京医科大学に設置した位置決め装置 (シミュレー ター)について

東京医科大学放射線科

岡本十二郎・網野 三郎・渡理 正英

田中吉男 ·沢柳 久嘉 $\cdot$ 国府田幸雄

島津製作所

平山嘉昭

[目的]

放射線治療を行なう場合に病巣位置，その抎がり，お よび健康重要臓器をさける様にして照射範囲の決定を行 なうために，治療計画用X線装置（シミュレーター）が 設置される様になり我国です3〜4の病院で供えている. 